abused my usurped license of wandering from my text.

\section{University of Chicago.}

The Story of the Atmosphere. By DougLas ARChIBALD. Published in the Library of Useful Stories. New York, D. Appleton, \& Co. 1897. Price, 40 c.

In the 'Story of the Atmosphere,' Mr Archibald has given us an excellent popular account of the most important features of modern deductive meteorology. His success in presenting the subject in such an elementary manner is really remarkable, and is without doubt due to his many years' interest in this branch of the science. Few Englishmen appear to have been greatly attracted by the deductive treatment of meteorology, and those who have shown by their writings that they have been pursuing this line of study have been most strongly represented by the Indian meteorologists, and foremost and earliest among these must be placed Blanford; and no Englishman has followed his lead more closely than Mr. Archibald, whose writings have received well merited attention during the past fifteen or twenty years.

It is, then, with the knowledge that Mr. Archibald is thoroughly familiar with his subject that we enter upon the perusal of his book ; and, as we finish it, we must admit it to be an important and very satisfactory addition to our popular science literature.

Mr. Archibald has shown great skill in selecting the material that he presents to the reader, and he has given it in a very interesting man. ner. It is, however, more of a student's book than might appear at first sight. It is just the book for a well educated man or woman to take up and read as supplementary to studies formerly pursued in schools, and in the hands of a teacher of meteorology or physical geography it will prove a valuable addition to the elementary text-books on those sciences.

Mr. Archibald's remarks on the origin and height, nature and composition, pressure and weight, of the atmosphere are clear and interesting; but the chief value of the book, in the eyes of a specialist, lies in the chapters on the temperature and motions of the atmospheric air. In these the author gives the reader the full benefit of his study of meteorological literature of various lands during the last score of years; during which time dynamical meteorology has made remarkable advances as a science, owing to the labor of various eminent physicists who have devoted considerable attention to it. In this portion of the book Ferrel's work has been given the prominence which it deserves, and the subjects presented have probably never been given in a clearer manner. It is interesting to note that the author has wisely reproduced some of Ferrel's original diagrams which have historic value.

Probably the most interesting chapter to the average reader is the one on 'Suspension and Flight in the Atmosphere.' This gives a succinct account of aërial navigation of all kinds-bird flights, ballooning, kite flying, air ships, etc. The various problems pertaining to these are elucidated and commented on with great discrimination. The last chapter deals very briefly but suggestively with 'Climate and Life in the Atmosphere.'

\section{Frank Waldo.}

Great Smoky Mountains, N. C.

\section{NEW BOOKS.}

Researches in the Uloa Valley, Honduras; Caverns of Copan. George Byron Gordon. Cambridge, published by the Peabody Museum. 1898. Pp. 44 and 12 Plates.

Catalogue of Scientific Periodicals, 1865-1895. H. Carrington Bolton. Second Edition, 1897. Washington, Smithsonian Institution. 1898. Pp. vii +1247 .

Forestry Conditions in Northern Wisconsin. FILIBERT Roth. Madison, Published by the State. 1898. Pp. vi +78 .

Instincts and Habits of the Solitary Wasps. George W. Peckham and Elizabeth G. Peckeam. Madison. 1898. Pp. iv +245 and 14 Plates.

Symons' British Rainfall, 189\%. G. J. Symons and H. SowErBY WALLACE. London, Stanford. 1898. Pp. 239.

Calcul des conduites d'eau. G. DARIEs. Paris, Gauthier-Villars et fils. 1898. Pp. 194. 